\title{
EFFECTIVENESS OF CHITOSAN TO REDUCE THE COLOR VALUE, TURBIDITY, AND TOTAL DISSOLVED SOLIDS IN SHRIMP-WASHING WASTEWATER
}

\author{
Hidayati Nurul Faridah*, Rahman Mijani, Fauzana Noor Arida, Aisiah Siti \\ Postgraduate Program of Natural Resources and Environmental Management, \\ University of Lambung Mangkurat, Banjarbaru, Indonesia \\ *E-mail: nurulfaridah.ssi@gmail.com
}

\begin{abstract}
This research aims to identify the optimum concentration of chitosan solution and the effectiveness of chitosan as a biocoagulant in shrimp-washing wastewater on three types of water quality parameters, i.e., color, turbidity, and total dissolved solids (TDS). By employing the jar test method, the coagulation-flocculation test was performed by adding chitosan doses of 0 ppm (control), 50 ppm, 100 ppm, 150 ppm, 200 ppm, and 250 ppm, respectively. The effectiveness of chitosan was measured by calculating the percentage decrease in color, turbidity, and TDS parameters in the treated shrimp-washing wastewater samples. The statistical analysis results indicated that the treatment had a significant effect on the three types of parameters, with the obtained optimum concentration of chitosan solution of 200 ppm. The effectiveness of chitosan in reducing color (84\%), turbidity $(83 \%)$, and TDS (54\%).
\end{abstract}

\section{KEY WORDS}

Chitosan, biocoagulant, coagulation-flocculation, optimum dose.

Indonesia is a country with the second-longest coastline globally, which becomes a supporting factor for Indonesia's fishery industry development. In addition to the positive impacts on the food sector and economy, the fishery industry development also negatively impacts the environment. According to Basuki \& Sanjaya (2009), Indonesia has approximately 170 shrimp processing industries with a built-in production capacity of around 500,000 tons/year. The amount of liquid waste generated from the freezing industry of fishery products, including frozen shrimp processing, reaches $14.9 \mathrm{~m}^{3} /$ ton of product (Ibrahim, 2005). Meanwhile, clean water in large quantities utilized as the primary input in the production process of the fishery product processing industry reaches $20 \mathrm{~m}^{3} /$ ton of product. Additionally, water is used in almost all relatively complex production processes, one of which is in the raw materials washing process. The raw materials washing process is generally conducted repeatedly to avoid bacterial contamination. The raw material washing wastewater is a liquid waste source from the fishery industry, including the frozen shrimp processing industry.

Chitosan is poly-(2-amino-2-decks- $\beta$-(1-4)-D-glucopyranose) with the molecular formula $\left(\mathrm{C}_{6} \mathrm{H}_{11} \mathrm{NO}_{4}\right) \mathrm{n}$ obtained from the chitin deacetylation (Sugita et al., 2009). Chitosan refers to an eco-friendly (Wardhani et al., 2014), non-toxic, biodegradable, renewable, and reactive natural biocoagulant (Ihsani \& Widyastuti, 2014). Chitosan is helpful in various fields, contributing to reducing environmental pollution since it is effectively applied in water and wastewater purification. The optimum concentration of chitosan solution utilized as a biocoagulant varies in each type of treated water or wastewater. As a coagulant in the wastewater treatment of the fishery industry, chitosan functions well in the concentration ranging from $175-225$ ppm with an optimum dose of 200 ppm (Ibrahim et al., 2009). Chitosan is effective in water purification, reduction of color value (Purwaningsih et al., 2020), turbidity (Nugraheni et al., 2014), and TDS (Nuralam et al., 2012). This research aims to analyze the optimum concentration of chitosan solution as a biocoagulant and its effectiveness in reducing color, turbidity, and TDS parameters in shrimp-washing wastewater. 


\section{MATERIALS AND METHODS OF RESEARCH}

The materials used in this research included the samples of shrimp-washing wastewater obtained from the shrimp processing unit of PT Kalimantan Fishery in Banjarmasin, South Kalimantan, commercial chitosan, $2 \%$ acetic acid, distilled water, and filter paper. The instruments utilized included a portable flocculator, magnetic stirrer, turbidity meter, portable data logging spectrophotometer, TDS meter, Beaker glass, Erlenmeyer, pipette, volumetric flask, and funnel.

The design used in this study was a completely randomized design (CRD) with six treatments and 4 replications, namely: Shrimp-washing wastewater chitosan solution $0 \mathrm{ppm}$; Shrimp-washing wastewater + addition $50 \mathrm{ppm}$ of chitosan solution 1\%; Shrimp-washing wastewater + addition $100 \mathrm{ppm}$ of chitosan solution 1\%; Shrimp-washing wastewater + addition $150 \mathrm{ppm}$ of chitosan solution 1\%; Shrimp-washing wastewater + addition $200 \mathrm{ppm}$ of chitosan solution 1\%; Shrimp-washing wastewater + addition 250 ppm of chitosan solution $1 \%$.

The preparation of $1 \%$ chitosan solution referred to the Prayudi \& Susanto (2000). The preparation was performed by dissolving 1 gram of chitosan powder into $20 \mathrm{~mL}$ of $2 \%$ acetic acid. Afterward, it was continued by adding $100 \mathrm{~mL}$ of distilled water and stirring the solution using a magnetic stirrer to ensure that the chitosan was well-dissolved.

The stages of coagulation-flocculation in this research referred to Ratnawulan et al. (2018). The samples of $1,000 \mathrm{~mL}$ shrimp-washing wastewater were prepared in 6 Beaker glasses, while the coagulation-flocculation test was executed by employing the jar test method. Chitosan solutions $1 \%$ with concentrations of $0 \mathrm{ppm}$ (control), $50 \mathrm{ppm}, 100 \mathrm{ppm}$, $150 \mathrm{ppm}, 200 \mathrm{ppm}$, and $250 \mathrm{ppm}$ were added to the samples while mixing the solution at 200 rpm 1 minute. The process was followed by slow mixing at $50 \mathrm{rpm}$ in 30 minutes. After the mixing process, the samples were deposited for 30 minutes before they were filtered. The sample parameters, including color, turbidity, and TDS, were measured after the treatment.

The effects of the treatment provided, in this case, the amount of chitosan solution concentrations on the shrimp-washing wastewater, could be determined using the KruskalWallis method of data analysis at a $95 \%$ confidence level. The normality of data was analyzed using the Shapiro-Wilk test, while the homogeneity of data was analyzed using Levene's test. The Mann-Whitney $U$ test was conducted to determine the treatments of chitosan solution concentrations resulting in significant differences. The statistical test tool employed was IBM SPSS version 25.0. The percentage calculation of the decrease in color, turbidity, and TDS parameters was performed to determine the effectiveness of chitosan as a biocoagulant in shrimp-washing wastewater using the formula: $E f=(A-B) / A \times 100 \%$, where $A$ represents the initial value of the parameters. In contrast, $B$ represents the final value of the parameters after the treatment.

\section{RESULTS OF STUDY}

Color, turbidity, and TDS parameters were tested after the samples were treated with coagulation-flocculation using the jar test method. The research results suggested that 200 ppm was the optimal concentration of chitosan solution to reduce the color value, turbidity, and TDS in shrimp-washing wastewater samples.

Table 1 - Results of the Control and Treatment of Various Chitosan Solutions Concentrations

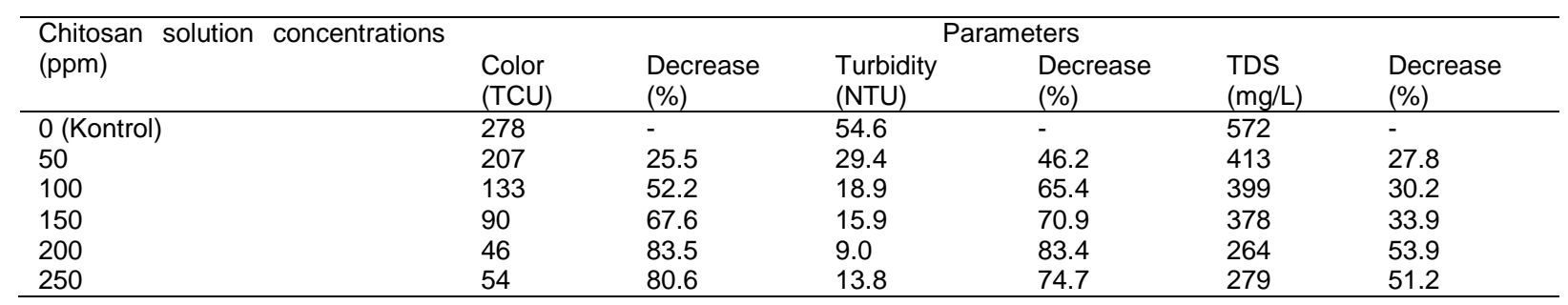

Note: The data obtained from four repeated treatments 
RJOAS, 7(115), July 2021

Table 2 - Results of Statistical Analysis using Kruskal-Wallis Test

\begin{tabular}{llll}
\hline & Color (TCU) & Turbidity (NTU) & TDS (mg/L) \\
\hline Kruskal Wallis H & 22.410 & 22.332 & 22.400 \\
df & 5 & 5 & 5 \\
Asymp. Sig. & 0.000 & 0.000 & 0.000 \\
\hline
\end{tabular}

\section{Color}

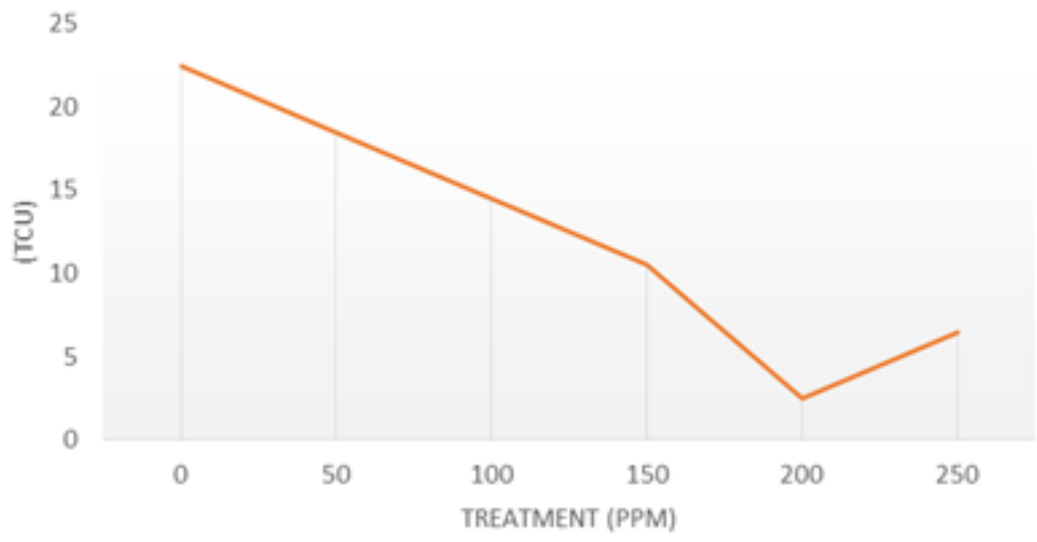

Figure 1 - Chitosan Concentration Effects on the Color Value

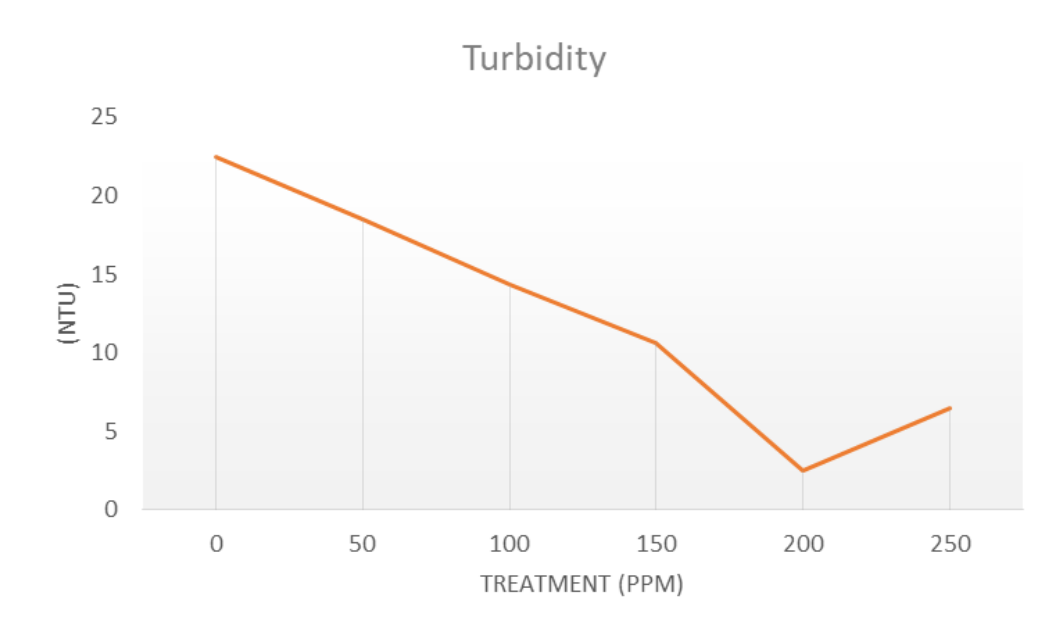

Figure 2 - Chitosan Concentration Effects on the Turbidity Value

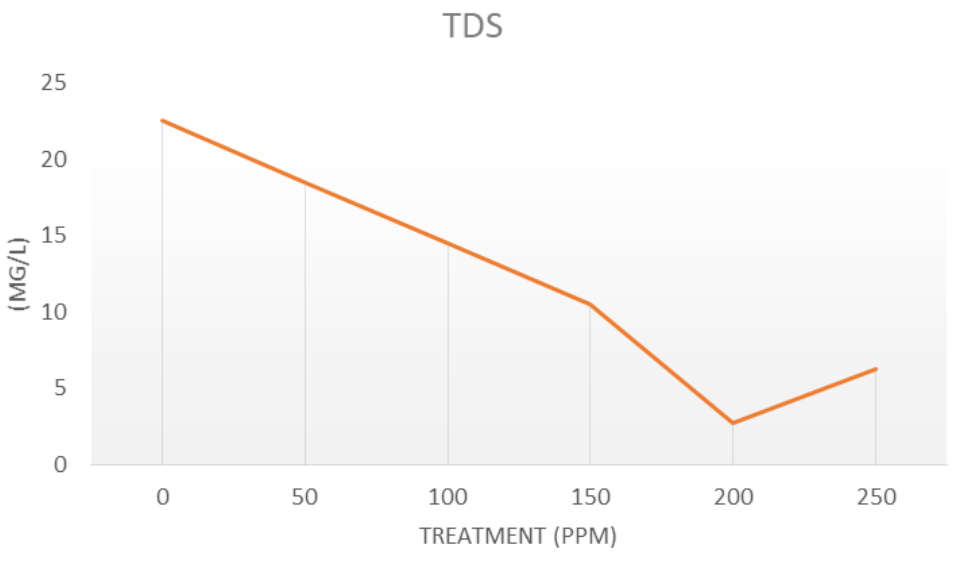

Figure 3 - Chitosan Concentration Effects on the TDS Value 
Based on the statistical analysis results, it can be concluded that the treatment of the various concentrations of chitosan solutions caused significant effects on color, turbidity, and TDS parameters. The Mann-Whitney $U$ test results that significantly different treatment for color, turbidity, and TDS was between 0 ppm and 200 ppm, 0 ppm and 250 ppm, 50 ppm and $200 \mathrm{ppm}$.

\section{DISCUSSION OF RESULTS}

There have been many studies on the application of chitosan coagulants in reducing pollutants in wastewater. The optimum concentration of chitosan solution utilized as a biocoagulant varies in each type of treated water or wastewater. Chitosan coagulant worked optimally at a concentration of 20 ppm in improving lake water quality (Hendrawati et al., 2015). The use of chitosan as a water purification coagulant with an optimum dose of $4 \mathrm{ppm}$ for river water (Mustafiah et al., 2018) and $150 \mathrm{ppm}$ effectively reduced 68\% of turbidity in reservoir water (Amalia, 2018). The optimum dose of chitosan as a coagulant in laundry wastewater treatment was 200 ppm (Joko et al., 2016), while the optimum dose of chitosan for textile wastewater treatment varied depending on the dye used.

Additionally, chitosan as a coagulant in the processing of fishery industry wastewater functioned properly within the concentration, ranging from $175-225 \mathrm{ppm}$ with an optimum dose of 200 ppm (Ibrahim et al., 2009). The results of the previous studies suggested that the use of chitosan with concentrations exceeding the optimum limit would raise back some water quality parameters, such as color and turbidity. It confirmed that optimizing the coagulant concentration was crucial to run the coagulation process effectively.

The jar test is the most common method to evaluate and optimize the coagulationflocculation process (Muruganandam et al., 2017). The jar test works to determine the optimum dose of the coagulant used in water processing or wastewater treatment. Chitosan contains several intrinsic characteristics that make it a coagulant and/or flocculant, which effectively removes contaminants in the dissolved conditions (Renault et al., 2009). The addition of chitosan as a biocoagulant in the coagulation-flocculation process helps accelerate the formation of larger, stronger, and more stable flocs (Joko et al., 2016). The flocculation-coagulation process aims to remove non-precipitating particles or colloids by adding a coagulant to the raw water followed by rapid stirring or coagulation and slow stirring or flocculation. It results in colloidal particle agglomeration, which then can be separated mainly in the sedimentation process. The coagulation aims to destabilize colloidally and suspend solid particles, while the purpose of flocculation is to accelerate collisions that induce the formation of unstable colloid particles so that they can be deposited (Nugraheni et al., 2014).

Table 1 displays the treatment through the coagulation-flocculation process with the addition of the most suitable chitosan concentration at $200 \mathrm{ppm}$ with the color value of 46 TCU, turbidity value of $9.0 \mathrm{NTU}$, and TDS value of $264 \mathrm{mg} / \mathrm{L}$. Based on the Kruskal-Wallis test results, the p-value was less than 0.05 for the color, turbidity, and TDS parameters. It means there were statistically significant differences in $\mathrm{pH}$, color, turbidity, and TDS values due to the treatment of adding various concentrations of chitosan solutions. Kruskal-Wallis is an omnibus test that can only detect significant differences statistically without knowing which treatments are different. Therefore, a post-hoc test is required. The Mann-Whitney $U$ test was carried out to identify the difference between one treatment and another.

Visually, the shrimp-washing wastewater had a slightly muddy brown color. The color of the wastewater indicated its quality. The new wastewater would be gray, while the stale or foul wastewater would have a darker color (Mahida, 1984). The addition of chitosan solution reduced the color value from $278 \mathrm{TCU}$ to $46 \mathrm{TCU}$ or $83.5 \%$ at a concentration of $200 \mathrm{ppm}$, as indicated in Table 1. The reason was that the higher the coagulant dose, the more dye molecules were trapped along the chitosan polymer chains and eventually agglomerated to form flocs. Increasing the coagulant dose resulted in more floc formation, significantly decreasing the color value (Tchobanoglous \& Eddy, 1991). The addition of chitosan solution at a concentration of $250 \mathrm{ppm}$ increased the color value back to $54 \mathrm{TCU}$ or $80.6 \%$. The 
reason was, with excessive agitation, the destabilized particles forming flocs turned back stable, and the flocs in the wastewater disunited. Consequently, the dye molecules trapped in the flocs unraveled (Purwaningsih et al., 2020).

Turbidity is the parameter that should be measured to check the efficiency of the flocculation-coagulation process (Hendrawati et al., 2009). Turbidity may be caused by organic and inorganic suspended solids in water. The statistical analysis results stated that the concentration of chitosan solution had various actual effects on wastewater turbidity. Table 1 presents that the most suitable turbidity value of 9.0 NTU was generated at a concentration of $200 \mathrm{ppm}$. According to Nugraheni et al. (2014), the higher the coagulant dose, the greater the turbidity removal efficiency in wastewater. The increase of turbidity removal efficiency value was caused by coagulant addition at an optimal dose that helped bind the contaminant and then turned the stable turbidity-causing fine particles into unstable. Therefore, it creates an attractive force that deposits the fine particles, forming flocs on the floor. In this case, the attractive force is greater than the repulsive force, resulting in a smooth deposition process of colloidal particles in turbid water (Tarigan, 2011). The reduced turbidity content was also induced by coagulants that help the floc formation (Kalpikawati, 2006). The chitosan concentration increase to $250 \mathrm{ppm}$ was found to increase the turbidity value back to 13.8 NTU. Hendrawati et al. (2015) reported that the addition of a coagulant exceeding the optimum limit would cause an increase in the value of turbidity due to excessive solutes. The result of a similar study was also reported by Mustafiah et al. (2018) that the addition of $2 \mathrm{ppm}$ and $4 \mathrm{ppm}$ chitosan solution in samples of river water could reduce the turbidity respectively $88.84 \%$ and $98.63 \%$. The addition of a higher concentration of the coagulant caused the turbidity to increase.

Total Dissolved Solids contains various solutes, including organic, inorganic, and other materials, with a diameter less than $10^{-3} \mu \mathrm{m}$ in the solution dissolved in the water (Mukhtasor, 2007). The TDS analysis is required to determine the pollution load and design the biological wastewater treatment system (llyas et al., 2013). The changes in the TDS concentration can be dangerous since they cause changes in salinity, ion composition, and toxicity of each ion. Changes in salinity can disturb the aquatic biota and biodiversity, generate less tolerant species, and cause high toxicity on an organism's life cycle (Weber-Scannell \& Duffy, 2007). The results of the Kruskal-Wallis analysis test suggested that the treatment of given variations in chitosan concentration significantly influenced the value of the TDS samples. Table 1 presents that the addition of chitosan solution could reduce the TDS level in the shrimp-washing wastewater up to $53.9 \%(264 \mathrm{mg} / \mathrm{L})$ in the concentration of $200 \mathrm{ppm}$ and $51.2 \%(279 \mathrm{mg} / \mathrm{L})$ in the concentration of $250 \mathrm{ppm}$. According to Hatma et al. (2021) suggested that the addition of chitosan made the solid content in the lake water decrease. The TDS analysis conducted by Nuralam et al. (2012) also indicated that the TDS level in the river water samples with $61.88 \%-79.38 \%$ and swamp water with $78.24 \%-88.05 \%$ decreased with the addition of a 3 gram chitosan dose. As a biocoagulant, chitosan is passable to be used as an alternative to improve water quality in reducing solid content.

The results of comparison between control and the samples treated with the optimum chitosan concentration of $200 \mathrm{ppm}$ could reduce the color value to $84 \%$, turbidity to $83 \%$, and TDS to $54 \%$. Chitosan in the optimum concentration of $200 \mathrm{ppm}$ could contribute as a biocoagulant in the shrimp-washing wastewater in the frozen shrimp processing industry. Compared to synthetic coagulants, chitosan is a non-toxic, biodegradable, polyelectronic, and reactive coagulant, such as protein. The coagulant of chitosan is eco-friendly material since it does not contain hazardous materials and has high added value (Mustafiah et al., 2018).

\section{CONCLUSION}

The addition of chitosan as a biocoagulant is considered effective in reducing the color value, turbidity, and TDS in shrimp-washing wastewater with an optimum chitosan concentration of $200 \mathrm{ppm}$. Chitosan effectively reduces the color value to $84 \%$, turbidity to $83 \%$, and TDS to $54 \%$. 


\section{REFERENCES}

1. Amalia, A. N. (2018). Pemanfaatan Cangkang Rajungan Sebagai Koagulan Untuk Penjernih Air. Skripsi. Universitas Islam Indonesia, Yogyakarta.

2. Basuki, B. R., \& Sanjaya, I. G. M. (2009). Sintesis Ikat Silang Kitosan dengan Glutaraldehid serta Identifikasi Gugus Fungsi dan Derajat Deasetilasinya. Jurnal IImu Dasar, 10(1), 93-101.

3. Hatma, S., Yani, S., \& Suryanto, A. (2021). Optimalisasi Penggunaan Kitosan Limbah Kulit Udang Vannamei sebagai Koagulan dalam Perbaikan Kualitas Air Danau. Jurnal Indonesia Sosial Sains, 2(2), 300-310.

4. Hendrawati, H., Sumarni, S., \& Nurhasni. (2015). Penggunaan Kitosan sebagai Koagulan Alami dalam Perbaikan Kualitas Air Danau. Jurnal Kimia VALENSI, 1(1), 1-11. doi:10.15408/jkv.v0i0.3148

5. Ibrahim, B. (2005). Kaji Ulang Sistem Pengolahan Limbah Cair Industri Hasil Perikanan Secara Biologis dengan Lumpur Aktif. Jurnal Pengolahan Hasil Perikanan Indonesia, 8(1), 31-41. doi:10.17844/jphpi.v8i1.1028

6. Ibrahim, B., Suptijah, P., \& Prantommy. (2009). Pemanfaatan Kitosan pada Pengolahan Limbah Cair Industri Perikanan. Jurnal Pengolahan Hasil Perikanan Indonesia, 12(2), 154-166. doi:10.17844/jphpi.v12i2.879

7. Ihsani, S. L., \& Widyastuti, C. R. (2014). Sintesis Biokoagulan Berbasis Kitosan dari Kulit Udang untuk Pengolahan Air Sungai yang Tercemar Limbah Industri Jamu dengan Kandungan Padatan Tersuspensi Tinggi. Jurnal Bahan Alam Terbarukan, 3(2), 66-70. doi:10.15294/jbat.v3i2.3700

8. Ilyas, N. I., Nugraha, W. D., \& Sumiyati, S. (2013). Penurunan Kadar TDS Pada Limbah Tahu dengan Teknologi Biofilm Menggunakan Media Biofilter Kerikil Hasil Letusan Gunung Merapi dalam Bentuk Random. Jurnal Teknik Lingkungan, 2(3), 1-10.

9. Joko, T., Agustin, D., Putri, C., \& Lanang, H. (2016). Chitosan on Reducing Chemical Oxygen Demands in Laundry Waste Water. International Journal of Sciences: Basic and Applied Research (IJSBAR), 4531(1), 104-111.

10. Kalpikawati, I.A. (2006). Sistem Pengolahan dan Kualitas Air Limbah Domestik di Bandar Udara Ngurah Rai Tuban Bali. Tesis. Universitas Udayana, Bali.

11. Mahida, U. N. (1984). Pencemaran Air dan Pemanfaatan Limbah Industri. Jakarta: CV. Radjawali.

12. Tchobanoglous, G \& Eddy, H. P. (1991). Wastewater Engineering: Treatment, Disposal, and Reuse (Vol. 4). McGraw-Hill New York.

13. Mukhtasor, I. (2007). Pencemaran: Pesisir dan Laut. Jakarta: PT. Pradnya Paramita.

14. Muruganandam, L., Kumar, M. P. S., Jena, A., Gulla, S., \& Godhwani, B. (2017). Treatment of Waste Water by Coagulation and Flocculation using Biomaterials. IOP Conference Series: Materials Science and Engineering, 263(3), 32006. IOP Publishing.

15. Mustafiah, M., Darnengsih, D., Sabara, Z., \& Abdul Majid, R. (2018). Pemanfaatan Kitosan dari Limbah Kulit Udang sebagai Koagulan Penjernihan Air. Journal Of Chemical Process Engineering, 3(1), 21. doi:10.33536/jcpe.v3i1.190

16. Nugraheni, D. T., Sudarno, S., \& Hadiwidodo, M. (2014). Cangkang Udang sebagai Biokoagulan Untuk Penyisihan Turbidity, TSS, BOD, Dan COD pada Pengolahan Air Limbah Farmasi PT. Phapros Tbk, Semarang. Jurnal Teknik Lingkungan, 3(4), 1-10.

17. Nuralam, E., Arbi, B. P., \& Prasetyowati. (2012). Pemanfaatan Limbah Kulit Kepiting menjadi Kitosan sebagai Penjernih Air pada Air Rawa dan Air Sungai. Jurnal Teknik Kimia, 18(4), 14-20.

18. Prayudi, T., \& Susanto, J. P. (2000). Chitosan sebagai Bahan Koagulan Limbah Cair Industri Tekstil. Jurnal Teknologi Lingkungan, 1(2), 121-125. doi:10.29122/jtl.v1i2.171

19. Purwaningsih, D. Y., Anisa, D., \& Putri, A. D. O. (2020). Kitosan Sebagai Koagulan untuk Removal Warna pada Limbah Cair Industri Pangan. Seminar Nasional Sains Dan Teknologi Terapan VIII, 541-546. Surabaya: Institut Teknologi Adhi Tama.

20. Ratnawulan, A., Noor, E., \& Suptijah, P. (2018). Pemanfaatan Kitosan dalam Daur Ulang Air sebagai Aplikasi Teknik Produksi Bersih. Jurnal Pengolahan Hasil Perikanan 
Indonesia, 21 (2), 276-286.

21. Renault, F., Sancey, B., Badot, P.-M., \& Crini, G. (2009). Chitosan for Coagulation/Flocculation Processes-An Eco-Friendly Approach. European Polymer Journal, 45(5), 1337-1348.

22. Sugita, P., Wukirsari, T., Sjahriza, A., \& Wahyono, D. (2009). Kitosan: Sumber Biomaterial Masa Depan. Bogor: IPB Press.

23. Tarigan, A. (2011). Pemanfaatan Serbuk Daun Asam Jawa (Tamarindus indica) sebagai Biokagulan untuk Menurunkan Konsentrasi Turbidity, TSS, BOD, dan COD dalam Pengolahan Limbah Cair Industri Tahu. Tesis. Universitas Diponegoro, Semarang.

24. Wardhani, W. K., Hadiwidodo, M., \& Sudarno, S. (2014). Khitin Cangkang Rajungan (Portunus Pelagicus) Sebagai Bikoagulan Untuk Penyisihan Turbidity, TSS, BOD Dan COD pada Pengolahan Air Limbah Farmasi PT. Phapros Tbk, Semarang. Jurnal Teknik Lingkungan. 3(4): 1-6.

25. Weber-Scannell, P. K., \& Duffy, L. K. (2007). Effects of Total Dissolved Solids on Aquatic Organism: A Review of Literature and Recommendation for Salmonid Species. American Journal of Environmental Sciences. 3(1), 1-6. doi:10.3844/ajessp.2007.1.6 